\title{
Deslições da Tataravó Moderninha ${ }^{1}$
}

Keilla Cavalheiro Kaipper*

- Tatá!

- Oi "girl" ! de "girl"...

- Tatá, por favor, me chame de neta, de filha, sei lá, menos

- Ham?! Isso é coisa de velha, eu ainda estou mais ligada que rádio de preso. Enfim, o que você quer?

- Tatá, estou pensando em me separar. Estou mais perdida que cego em tiroteio.

- Por quê? Você sempre foi feliz que nem lambari em sanga, com seu marido.

- A senhora está mais por fora que surdo em bingo, heim?!

- Agora estou mais assustada que veia em canoa! O que eu não estou sabendo?

- José Eduardo está mais chato que chinelo de gordo, e mais feio que paraguaio baleado!

- Ah, eu não te falei?! Cavalo torto não dá carreira direita. O bom da vida é ser solteira!

- E o pior, Tatá, é que ele anda mais sério que defunto, calmo que nem água de poço, e não toma banho. Anda mais nojento que mocotó de ontem. Não aguento mais!

- Fogo de palha, chuva de verão e raiva de mulher tem pouca duração! É só uma má fase, momentos de deslize, logo ele se ajeita. Deve ser problema no trabalho.

1 Texto elaborado como atividade de produção textual no início do estudo da linguagem literária nas aulas de Língua Portuguesa ministradas pelo prof. Tadeu Rossato Bisognin no primeiro ano do Ensino Médio. Os alunos observam as variações de sentido, metáforas, comparações e outros recursos estilísticos em diferentes provérbios (Anexo 1). Após a leitura do texto Liçôes da bisavó de minha avó (Anexo 2), devem produzir um texto utilizando grande número de provérbios, assim como fez Donaldo Schüler. Para tanto, recebem uma listagem de provérbios e de ditados gaúchos (Anexos 3 e 4) para possível utilização em sua produção textual.

* Aluna do primeiro ano do Ensino Médio do CAp/UFRGS em 2010. 
- Trabalho? Que trabalho?! Ele foi despedido mês passado por ser mais boca-aberta que burro que comeu urtiga. Agora anda mais atirado que alpargata em cancha de bocha. Levar esse casamento adiante está mais difícil que nadar de poncho. Acreditas que esses dias entrou uma barata lá em casa?

$-\mathrm{E}$ aí?

- Bom, aí eu descobri que ele é mais medroso que cascudo atravessando galinheiro. Ficou mais nervoso que potro com mosca no ouvido, quando viu o bicho. E adivinha...

$-\mathrm{O}$ quê?

- Não quis matá-la!

- Ah! Ah! Ah! Que piada esse homem. Antes de você se casar já havia lhe dito que quem casa por amores sempre vive em dores! É melhor separar-se dele, e logo. Viva sua vida, homem não presta!

- Poxa vida, Tatá! Eu venho aqui mais angustiada que barata de ponta-cabeça, lhe pedir um conselho para salvar meu casamento, e a senhora me joga um balde de água fria?!

- Ah, eu achei que você queria apoio para acabar de vez o casamento com aquela mula. Você não me informou que era para eu mentir e fingir que estava tudo bem.

- A senhora nem sabia de nada do que estava acontecendo e agora vem me dizer que as coisas no meu casamento não estão indo bem? Ah, por favor né, a senhora anda mais grossa que dedo destroncado!

- O quê? Achei que seu casamento estava mais gasto que fundilho de tropeiro. Ops! Havia esquecido que sempre há um chinelo para um pé torto!

- Engraçadinha. Ah, quer saber de uma coisa?

- Meu marido anda mais gorduroso que telefone de açogueiro, mais feio que sapato de padre, mais devagarzito que enterro de viúva rica, mais chato que gilete caída em chão de banheiro, mas estar ainda com ele é mais gostoso que beijo de primo! 
- Vai entender essa juventude. Achei que era moda hoje em dia se separar. Depois a velha sou eu!

- E para encerrar de vez com essa tentativa de me separar...

- Tentativa de te separar? Eu?

- É! Vou deixar bem claro que meu casamento é mais quente que frigideira sem cabo!

- O quê? Não foi isso que você me disse! Ai, ai... Casco de boi velho, onde se assenta, não escorrega. Lembre-se disso! 


\section{Anexo I - Estudo de provérbios}

1) Dê o significado das citações/ditos abaixo:

1. Água mole em pedra dura tanto bate até que fura.

2. Antes tarde do que nunca.

3. Bater a porta na cara.

4. Tem boi na linha.

5. Calcanhar de Aquiles.

6. Carne de pescoço.

7. Presente de grego.

8. Gato escaldado tem medo de água fria.

9. Fiat lux.

10. Dourar a pílula.

2) Relacione as colunas:

1. Um dia é da caça, outro do caçador.

2. Cão que late não morde.

3. Quem sai na chuva é pra se molhar.

4. Quem não tem cão caça com gato.

5. Lágrimas de crocodilo.

6. Dar com os burros n’água.

7. Osso duro de roer.

8. Peixe fora d'água.

9. Filhinho de peixe peixinho é.

10. Quem tem pressa come cru.

11. Pôr o caro na frente dos bois.

12. Amigo da onça.

13. A vaca foi pro brejo.

14. Dormir com a s galinhas.
( ) Cada um deve cuidar de sue assuntos.

( ) Não há problema que resista à boa música.

( ) O filho herda qualidade $\mathrm{e}$ defeitos do pai.

( ) Se não dá pra resolve rum problema de um jeito, resolvese de outro.

( ) Ir para a cama logo que escurece.

( ) Fazer esforço para conseguir uma coisa e sair-se mal por algum motivo qualquer.

( ) Problema muito complicado.

( ) Sentir-se fora, deslocado. 
15. Em boca fechada não entra mosca.

16. Levar gato por lebre.

17. Cada macaco no seu galho.

18. Quem ri por último ri melhor.

19. História pra boi dormir.

20. Quem canta seus males espanta.
( ) Quem se arrisca deve arcar com as consequências. ( ) Quem é muito afobado acaba se dando mal.

( ) Não adianta começar uma tarefa pelo fim.

( ) Não se pode ter sorte sempre.

( ) Mentira ou conversa de quem não sabe do que está falando.

( ) Choro fingido.

( ) Ser enganado, acreditar em um mentira.

( ) Pessoa falsa, fingida.

( ) Não se deve comemorar antes da hora.

( ) É preciso tomar cuidado com o que se diz.

( ) Há gente que promete mil coisas e não faz nada.

( ) Dar tudo errado. 


\section{Anexo II - Lições da bisavó de minha avó}

- E se ele anda com as outras?

- Fecha o olho, minha filha. Com o que não vi, nunca me aborreci. De nada duvida quem de nada sabe.

- E se ele nunca janta em casa?

- Faz um curso de arte culinária. Marido se conquista pelo estômago. Guisado por mão de sinhá, quem não comerá.

- E se ele não me deixa sair de casa?

- Obedece. Lugar de homem é na rua, lugar de mulher é na cozinha. A formiga,quando quer perder-se, cria asas. Cuida dos teus filhos, a má ovelha deita o rebanho a perder. Gato e mulher em casa; homem e cachorro, na rua.

- E se ele me bate?

- Agüenta. Porrete de marido é carinho. Deus dá o frio conforme a roupa. Enqanto opau vai e vem, folgam as costas.

- Ele, quando está comigo, vive cansado.

- Dá beijinho nele. Mais vale marido cansado do que homem extraviado. Não esperes afeto de mão beijada. O que muito vale, muito custa.

- E se ele vai passear e não me leva?

- Fica. A casamento e batizado não vás sem ser convidado.

- Mas eu ando tão reclusa, que nem amigos tenho.

- À mulher casta, Deus lhe basta. A mulher e a galinha, com andar se perde asinha. Cavalo torto não dá carreira direita. Tanto vai o pote à bica, até que um dia lá fica.

- E se ele me xinga?

- Cala. Boca de fel, coração de mel. Não te ponhas a retrucar. Em boca fechada não entra mosca. Se ele vem bonzinho, fica com um pé atrás. Gato de luva, sinal de chuva. Mão fria, coração quente. Quem desdenha quer comprar.

- Mas eu estou com raiva, vovozinha.

- Isso passa, minha filha. Fogo de palha, chuva de verão e raiva de mulher tem pouca duração. $\mathrm{O}$ tempo tudo consome.

- Se tu visses como ele é mandão! 
- E tem que ser. Não faças de teu lar casa de pai Gonzalo, onde a galinha manda mais do que o galo. Mal vai a casa onde a roca vale mais do que a espada. A boi fraco todos pialam. Boi lerdo bebe água suja. Quem muito se abaixa, a bunda lhe aparece.

- Uma amiga me falou que eu devia reagir.

- Não dês ouvidos. Quem com criança se deita amanhece mijado. Mais há quem suje a casa do quem a varra. Dai-me dinheiro e não conselhos. Mais vale jeito que força. Quando um não quer, dois não brigam.

- Eu não aguento mais, vovozinha. Vou-me embora pra nunca mais voltar.

- Aguenta, sim, minha filha. Mau barbeiro arranca couro e cabelo. Não há miséria que traga fartura. Não há medalha sem reverso.

- Mas eu sofro tanto!

- Quem casa por amores sempre vive em dores.

- Isso foi no seu tempo, hoje e diferente, vovozinha.

- Não te iludas, filha. Casco de boi velho, onde assenta, não escorrega.

Eu disse o que a bisavó

Da minha avó me ensinou;

Se alguém sabe mais do que eu

Já não está aqui quem falou.

(SCHÜLER, Donaldo. Chimarrita. Porto Alegre: Movimento, 1986.) 


\section{Anexo III - Lista de provérbios}

Observe lista de provérbios para possível utilização em produção textual.

1. A cavalo dado não se olha os dentes.

2. A fome é a melhor cozinheira.

3. A galinha da vizinha é sempre melhor que a minha.

4. A justiça tarda mas não falha.

5. A noite é boa conselheira.

6. A ocasião faz o ladrão.

7. A preguiça é a mãe de todos os vícios.

8. A pressa é inimiga da perfeição.

9. Roupa suja se lava em casa.

10. A união faz a força.

11. As aparências enganam.

12. As paredes têm ouvidos.

13. Cada cabeça uma sentença.

14. Cada macaco no seu galho.

15. Cada um por si e deus por todos.

16. Cada um puxa a brasa para sua sardinha.

17. Cada um vê mal ou bem conforme os olhos que tem.

18. Cão que ladra não morde.

19. Casa de pais, escola de filhos.

20. Cavalo amarrado também pasta.

21. Com fogo não se brinca.

22. Caldo de galinha nunca fez mal a ninguém.

23. Deus dá nozes a quem não tem dentes.

24. Dar a César o que é de César, a Deus o que é de Deus.

25. De boas intenções o inferno está cheio.

26. De livro fechado não sai letrado.

27. Depois da tempestade vem a bonança.

28. Deus escreve direito por linhas tortas.

29. Devagar se vaia ao longe.

30. Diz-me com quem andas, dir-te-ei quem és. 
31. Em casa de ferreiro, espeto de pau.

32. Entre marido e mulher não se mete a colher.

33. Espera de teus filhos o que a teus pais fizeres.

34. Filhos criados, trabalhos dobrados.

35. Filho de burro não pode ser cavalo.

36. Filhos das minhas filhas meus netos são. Filhos dos meus filhos serão ou não.

37. Há males que vêm para o bem.

38. Homem prevenido vale por dois.

39. Ladrão que rouba ladrão tem cem anos de perdão.

40. Mais fere a palavra que a espada.

41. Mais homens se afogam num copo do que no mar.

42. Mais vale burro vivo do que sábio morto.

43. Mais vale prevenir do que remediar.

44. Mais vale um pássaro na mão do que dois voando.

45. Não há atalho sem trabalho.

46. Não há bem que sempre dure nem mal que nunca acabe.

47. Pior cego é aquele que não quer ver.

48. Não há regra sem exceção.

49. Não contar com ovo ainda dentro da galinha.

50. Não se fazem omeletes sem partir os ovos.

51. Nunca digas dessa água não beberei.

52. O barato sai caro.

53. O que não tem remédio remediado está.

54. O seguro morreu de velho.

55. O que os olhos não vêem o coração não sente.

56. Os erros dos médicos a terra cobre.

57. Panela velha é que faz boa sopa.

58. Quando a esmola é grande o santo desconfia.

59. Quanto mais depressa mais devagar.

60. Quem não arrisca não petisca.

61. Quem não chora não mama.

62. Quem não deve não teme.

63. Querer é poder.

64. Um burro carregado de livros é um doutor.

65. Vaso ruim não quebra. 


\section{Anexo IV - Ditados gaúchos}

1. Mais ligado que rádio de preso.

2. Firme que nem prego em polenta.

3. Saracoteando mais que bolacha em boca de veia.

4. Mais pesado que sono de surdo.

5. Mais amontoado que uva em cacho.

6. Mais perdido que cachorro em dia de mudança.

7. Mais perdido do que cusco em procissão.

8. Mais angustiado que barata de ponta-cabeça.

9. Mais por fora que surdo em bingo.

10. Feliz que nem lambari de sanga.

11. Mais apressado que cavalo de carteiro.

12. Mais atirado que alpargata em cancha de bocha.

13. De boca aberta que nem burro que comeu urtiga.

14. Mais chato que gilete caída em chão de banheiro.

15. Mais conhecido que parteira de campanha.

16. Mais cheio que corvo em carniça de vaca atolada.

17. Mais difícil que nadar de poncho.

18. Mais encolhido que tripa na brasa.

19. Mais faceiro que mosca em tampa de xarope.

20. Mais faceiro que ganso novo em taipa de açude.

21. Mais feio que sapato de padre.

22. Mais feio que indigestão de torresmo.

23. Mais por fora que cotovelo de caminhoneiro.

24. Mais gostoso que beijo de prima.

25. Mais grosso que rolha de poço.

26. Mais informado que gerente de funerária.

27. Mais medroso que cascudo atravessando galinheiro.

28. Mais nervoso que potro com mosca no ouvido.

29. Tranquilo que nem cozinheiro de hospício.

30. Mais gorduroso que telefone de açougueiro.

31. Mais perdido que cebola em salada de frutas.

32. Mais curto que coice de porco.

33. Mais nojento que mocotó de ontem. 
34. Mais curto que estribo de anão.

35. Calmo que nem água de poço.

36. Mais perdido que cego em tiroteio.

37. Mais assustado que véia em canoa.

38. Mais faceiro que guri de bombacha nova.

39. Mais por fora que quarto de empregada.

40. Mais sofrido que joelho de freira em semana Santa.

41. Mais ansioso que anão em comício.

42. Mais baixo que voo de marreca choca.

43. Mais bonita que laranja de amostra.

44. Mais comprido que cuspe de bêbado.

45. Mais comprido que puteada de gago.

46. Mais coxuda que leitoa em engorde.

47. Mais duro que salame de colônia.

48. Devagarzito como enterro de viúva rica.

49. Extraviado que nem chinelo de bêbado.

50. Mais faceiro que picapau em tronqueira.

51. Mais feio que briga de foice no escuro.

52. Mais feio que paraguaio baleado.

53. Mais firme que palanque em banhado.

54. Mais gasto que fundilho de tropeiro.

55. Mais grosso que dedo destroncado.

56. Mais grosso que parafuso de Patrola.

57. Mais quente que frigideira sem cabo.

58. Mais sério que defunto.

59. Mais sujo que pau de galinheiro.

60. Tranquilo que nem água de poço.

61. Mais feliz que gordo de camiseta.

62. Mais chato que chinelo de gordo. 
